\title{
Messenger RNA (mRNA)-based age determination using skin-specific markers of saliva epithelial cells
}

Onyekachi Ogbonnaya Iroanya * D, Josephine Chioma Obi, Olabisi Olanike Ogunyinka, Oluwayomi Temidayo Bosede, Tochukwu Frank Egwuatu and Richard Adeniyi Adewole

\begin{abstract}
Background: Age determination is a vital factor in biological identification in forensics. This study was carried out to determine the expression levels of three target genes (Keratin 9 (KRT9), Loricrin (LOR) and Corneodesmosin $(C D S N))$ in salivary epithelial cells and how they can be used in age determination using reference gene, $\beta$-actin. Thirty young adults participated in the study and were divided into three groups according to their ages (16-20, 21-25, and 26-30). Ribonucleic acid (RNA) extraction, complementary deoxyribonucleic acid (cDNA) synthesis and quantitative polymerase chain reaction (qPCR) were performed. Data analysis was done using IBM SPSS Version 26 and the comparative $\mathrm{Ct}$ method $\left(2^{-\Delta \Delta \mathrm{Ct}}\right.$ method).
\end{abstract}

Results: CDSN was detected in all the sampled age groups. Though the age group 16-20 had the highest (0.4237) expression of CDSN among the three age groups, there was no significant difference $(p>0.05)$ in the expression of the gene among the three age groups. The LOR gene was lowly expressed across all age groups used in the study. The expression of the gene did not significantly differ $(p>0.05)$ between the control and 26-30 years age group, but they were however significantly higher $(F=36.47, p \leq 0.05)$ than the expression of the gene in both $16-20$ and 21-25 years age groups. The KRT9 gene was expressed only in age groups 16-20 and 26-30 and the expression of the gene did not significantly $(p>0.05)$ differ between these age groups. Though the expression of all the target genes was low, it was observed that the LOR gene expression varied among 21-25 and 26-30 age groups; therefore, more data and further analyses are still required since this experimental approach for age determination using gene expression is still at an emerging stage.

Conclusion: Although RNA concentration was low and the expression values of the genes were low and could not be used in comparing the expression levels among the three age groups, it can be concluded that the three messenger ribonucleic acid (mRNA) markers CDSN, LOR and KRT9, as well as the ACTB reference mRNA marker analysed via the described qPCR assays, are suitable for identifying epithelial cells in saliva.

Keywords: Age determination, Keratin 9, Loricrin, Corneodesmosin, Salivary epithelial cells, Beta-actin, Ribonucleic acid, Complementary DNA, Quantitative PCR

*Correspondence: oiroanya@unilag.edu.ng; onyiiog@yahoo.com

Department of Cell Biology and Genetics, University of Lagos, Akoka Yaba, Lagos, Nigeria

(c) The Author(s). 2020 Open Access This article is licensed under a Creative Commons Attribution 4.0 International License, which permits use, sharing, adaptation, distribution and reproduction in any medium or format, as long as you give appropriate credit to the original author(s) and the source, provide a link to the Creative Commons licence, and indicate if changes were made. The images or other third party material in this article are included in the article's Creative Commons licence, unless indicated otherwise in a credit line to the material. If material is not included in the article's Creative Commons licence and your intended use is not permitted by statutory regulation or exceeds the permitted use, you will need to obtain permission directly from the copyright holder. To view a copy of this licence, visit http://creativecommons.org/licenses/by/4.0/. 


\section{Background}

The need for the development of novel techniques to assist the law in taking its course remains on the increase with the alarming rate of crimes and sexual assaults. Body fluid identification is a vital component in forensic investigations as it plays a great role in pinning down perpetrators of criminal acts. The body fluids of interest in forensic studies include blood, saliva, semen, vaginal discharge and menstrual blood. The information obtained from these body fluids are important and may assist in the successful resolution of judicial processes.

Saliva is a thick, colourless fluid of great importance that is secreted in human beings. It is produced and secreted from pairs of major salivary glands and several minor salivary glands. The basic secretary units of salivary glands are clusters of cells called acini [1]. Saliva has been progressively studied as a non-invasive and relatively stress-free diagnostic alternative to blood [2], and this has aroused great interest among researchers especially in the field of forensics. Its popularity as a fluid of interest in forensic analysis has been amplified by its similarity with plasma and the non-invasive, painless, easy and cost-effective method of collection, besides the relative safety associated with collecting and handling it. Although this biological fluid is easy to manipulate and collect, careful attention must be directed to limit variation in specimen integrity [3]. Whole saliva houses secretions released from the salivary glands (parotid glands, submandibular glands and sublingual glands) and gingival crevicular fluid and also contains desquamated oral epithelial cell [4]. Messenger RNA (mRNA) may provide the necessary specificity, sensitivity and automation capabilities that modern forensic biology laboratories require for cellular origin identification [5]. At a crime scene, the ability to ascertain the depositor of a biological fluid is crucial to forensic investigators. Determination of age and sex are important factors in forensic sciences.

The biological age of an individual is an advantageous biometric that may be open to molecular genetic analysis. Messenger RNA profiling is likely to play a major role in the future of forensic biochemistry, not only for the identification of body fluids and tissue, but also in the determination of the age of an individual (a stain donor) [6]. Recently, the analysis of cell-specific messenger RNA expression (mRNA profiling) has been proposed to supplant conventional methods for body fluid identification [7]. The basis of mRNA profiling in the identification of body fluid and tissue is the fact that each individual tissue type comprises of cells that have a unique transcriptome (i.e. mRNA) profile, that is, each cell type has its own transcriptome, and differences in expression patterns can be utilized to identify mRNA markers with strong overexpression in one relative to the other forensically relevant cell types (such as body fluids) [5].

Studies have revealed the presence of a mix of epithelial cells and leukocytes in varying proportions in saliva and buccal swab samples, especially in saliva [3, $8,9]$. The exfoliated epithelial cells from the oral mucosa constitute a significant cellular component in the saliva [10]. Buccal swab sampling has been recommended as the preferred method of choice to minimize cellular heterogeneity for downstream studies. However, chances of finding salivary donor compared to finding the saliva stain itself at a crime scene are slim. This emphasizes the need to characterize the transcriptome of epithelial cells of saliva samples and not those obtained from buccal swabs.

\section{Methods}

\subsection{Ethical approval}

Prior to sample collection, the research details were explained to all the participants after which they willingly consented to participate in the study. Questionnaires were completed by all the study participants and informed written consent was obtained. The study protocol was approved by the Health Research Ethics Committee (CMULHREC number, CMUL/HREC/10/19/618) of the University of Lagos, Nigeria.

\subsection{Study design}

Saliva samples from thirty healthy individuals were used for the analysis. The individuals were divided into three groups $(16-20,21-25,26-30)$ according to their age. Each group consisted of 10 individuals, 5 males and 5 females, respectively. Individuals were provided with forms to provide their details such as age and sex. Only individuals within the different age groups and with good oral health history participated in the research.

\subsection{Materials used for the study}

Ribonucleic acid (RNA) extraction, complementary DNA (cDNA) synthesis and quantitative PCR (qPCR) were performed using the Quick-RNA MiniPrep Kit, LunaScript RT SuperMix Kit (NEB \#E3010) and Luna Universal qPCR Master Mix Kit (NEB \#M3003), respectively. 


\subsection{Sample collection}

At least $2 \mathrm{ml}$ of unstimulated saliva was collected from each individual using the passive drooling method into a plain bottle. Individuals were advised not to consume anything $30 \mathrm{~min}$ before sample collection and to rinse their mouths with water and sit comfortably without swallowing and allow the saliva to accumulate in the floor of their mouth. After 5 min, they were asked to tilt their heads slightly forward, open their mouths and allow the saliva to flow into the plain bottle. The plain bottles containing the saliva samples were then placed in a cooler box prior to RNA extraction.

\subsection{Ribonucleic acid (RNA) extraction}

RNA was extracted using Quick-RNA MiniPrep Kit according to the manufacturer's instruction. The RNA isolation consists of three steps: sample lysis/ homogenization, sample clearing/genomic deoxyribonucleic acid (gDNA) removal and RNA purification. All steps were performed at room temperature $\left(20-30^{\circ} \mathrm{C}\right)$. RNA was stored at $-80^{\circ} \mathrm{C}$.

\subsection{Spectrophotometry}

RNA quality and quantity were determined spectrophotometrically by analysing absorption ratios: A260/ 230 and A260/280 using a Nanodrop 1000 spectrophotometer (6305 JENWAY spectrometer).

\subsection{Complementary DNA (cDNA) synthesis}

cDNA synthesis was done using the LunaScript RT SuperMix Kit (NEB \#E3010). The cDNA synthesis reaction was prepared by adding $4 \mu \mathrm{l}$ of LunaScript RT SuperMix (1×) to $10 \mu \mathrm{l}$ of the RNA sample and made up to $20 \mu \mathrm{l}$ with $6 \mu \mathrm{l}$ of nuclease-free water. The reactions were then incubated. The primers were allowed to anneal for $2 \mathrm{~min}$ at $25^{\circ} \mathrm{C}$ followed by cDNA synthesis which lasted for $10 \mathrm{~min}$ at $55^{\circ} \mathrm{C}$. The last stage of this process was heat inactivation which lasted for $1 \mathrm{~min}$ at $95^{\circ} \mathrm{C}$.

\subsection{Quantitative PCR (qPCR)}

qPCR was done using the Luna Universal qPCR Master Mix Kit (NEB \#M3003). Dye-based qPCR detection was prepared using $10 \mu \mathrm{l}$ of Luna Universal qPCR Master Mix (1×), $0.5 \mu \mathrm{l}$ of $10 \mu \mathrm{M}$ forward primer $(0.25 \mu \mathrm{M})$, $0.5 \mu \mathrm{l}$ of $10 \mu \mathrm{M}$ reverse primer $(0.25 \mu \mathrm{M}), 2 \mu \mathrm{l}$ of cDNA products and $7 \mu \mathrm{l}$ of nuclease-free water. Initial denaturation ( 1 cycle) was carried out for $60 \mathrm{~s}$ at $95^{\circ} \mathrm{C}$, denaturation (40-45 cycles) for $15 \mathrm{~s}$ at $95^{\circ} \mathrm{C}$ and extension (4045 cycles) for $30 \mathrm{~s}$ at $60^{\circ} \mathrm{C}$. Melt curve $(1 \mathrm{cycle})$ was determined at $60-95^{\circ} \mathrm{C}$ for $60 \mathrm{~s}$.

\subsection{Primers}

The primer sequences for the target genes and reference gene were designed on PrimerBlast and validated on NetPrimer and Oligoanalyzer (Table 1).

\subsection{Statistical analysis}

All numeric data generated were analysed using IBM SPSS Version 26 [IBM SPSS Inc., USA]. Analysis of variance (ANOVA) was used to compare group mean values and mean differences were separated using Duncan multiple range test at 5\% level of significance. Graphs were plotted using GraphPad 8.0.1 software. The comparative threshold cycle (CT) method ( $2^{-\Delta \Delta C t}$ method) was used to analyse the expression level of the target genes as described by Ren et al. [11].

\section{Results}

\subsection{Spectrophotometry}

Absorbance ratios for $A_{260} / A_{280}$ and $A_{260} / A_{230}$ were determined for $1 \mu \mathrm{l}$ of each sample using a Nanodrop $1000 \mathrm{spec}-$ trophotometer (6305 JENWAY). The values were low in all the samples. Only samples with RNA concentrations of 1.0 $\mathrm{ng} / \mu \mathrm{l}$ and above were included in the analysis. Correlation analysis of the spectrophotometric values revealed that RNA quality measured at 260/230 absorbance significantly correlated $(p<0.01)$ with RNA yield $(\mathrm{ng} / \mu \mathrm{l})$. Other parameters measured showed no correlations with one another (Table 2).

Table 1 Primer sequences

\begin{tabular}{ll}
\hline Genes & Primer sequences \\
\hline Beta-Actin (ACTB) & Forward primer-5'-GACCTGTACGCCAACACAGT-3' \\
Corneodesmosin (CDSN) & Reverse primer-5'-CTCCTTCTGCATCCTGTCGG-3' \\
Keratin9 (KRT9) & Forward primer-5'-CTCCTTCTGCATCCTGTCGG-3' \\
& Reverse primer-5'-GGAACCGGATGCACCTTGTA-3' \\
Loricrin (LOR) & Forward primer-5'-AGTTGGAGGTGTTTCCAGGG-3' \\
& Reverse primer-5'-TGGGGTTGGGAGGTAGTTGT-3' \\
\hline
\end{tabular}


Table 2 Correlation analysis between RNA quality and yield

\begin{tabular}{lllll}
\hline & $260 / 280$ & $260 / 230$ & $\mathrm{ng} / \mu \mathrm{l}$ & Age \\
\hline $260 / 280$ & 1.000 & 0.302 & 0.364 & 0.315 \\
$260 / 230$ & & 1.000 & $0.717^{* *}$ & 0.110 \\
$\mathrm{ng} / \mu \mathrm{l}$ & & 1.000 & 0.225 \\
Age & & & 1.000 \\
\hline **Significant at $p<0.01$ & & &
\end{tabular}

\subsection{Quantitative PCR analysis for the CDSN gene}

qPCR analysis of the CDSN gene revealed that there was low expression of the gene among sampled age groups who participated in the study. Participants in the age group 16-20 had the highest expression of $C D S N$ among the three age groups. However, there was no significant difference in the expression of the gene among the three age groups $(p>0.05)$. The expression of the CDSN gene in the control $(\beta-$ actin) was significantly different $(F=17.08, p \leq$ $0.05)$ from its expression in all three age groups (Fig. 1/Table 3).

\subsection{Quantitative PCR analysis for the LOR gene}

qPCR analysis of the LOR gene reveals low expression of the gene across all age groups used in the study.
The expression of the gene did not significantly differ $(p>0.05)$ between the control $(\beta$-actin) and the age group 26-30, but they were however significantly higher $(F=36.47, p \leq 0.05)$ than the expression of the gene in both 16-20 and 21-25 age groups (Fig. 2/Table 4).

\subsection{Quantitative PCR analysis for the KRT9 gene}

qPCR analysis of the KRT9 gene revealed an expression of the gene only in age groups $16-20$ and $26-30$ and the expression of the gene did not significantly differ $(p>$ 0.05 ) between these age groups. The gene was not detected in the control ( $\beta$-actin) and $21-25$ age groups (Fig. 3/Table 5).

\subsection{Comparison of expression of the three genes used in the study}

Compared to other genes, CDSN had the highest expression across all the age groups including the control (Table 6). LOR had the lowest expression across all samples while KRT9 was only detected in age groups 16-20 and 26-30 (Fig. 4).

\section{Discussion}

Age determination has long been one of the most important goals of forensic scientists and the biological age
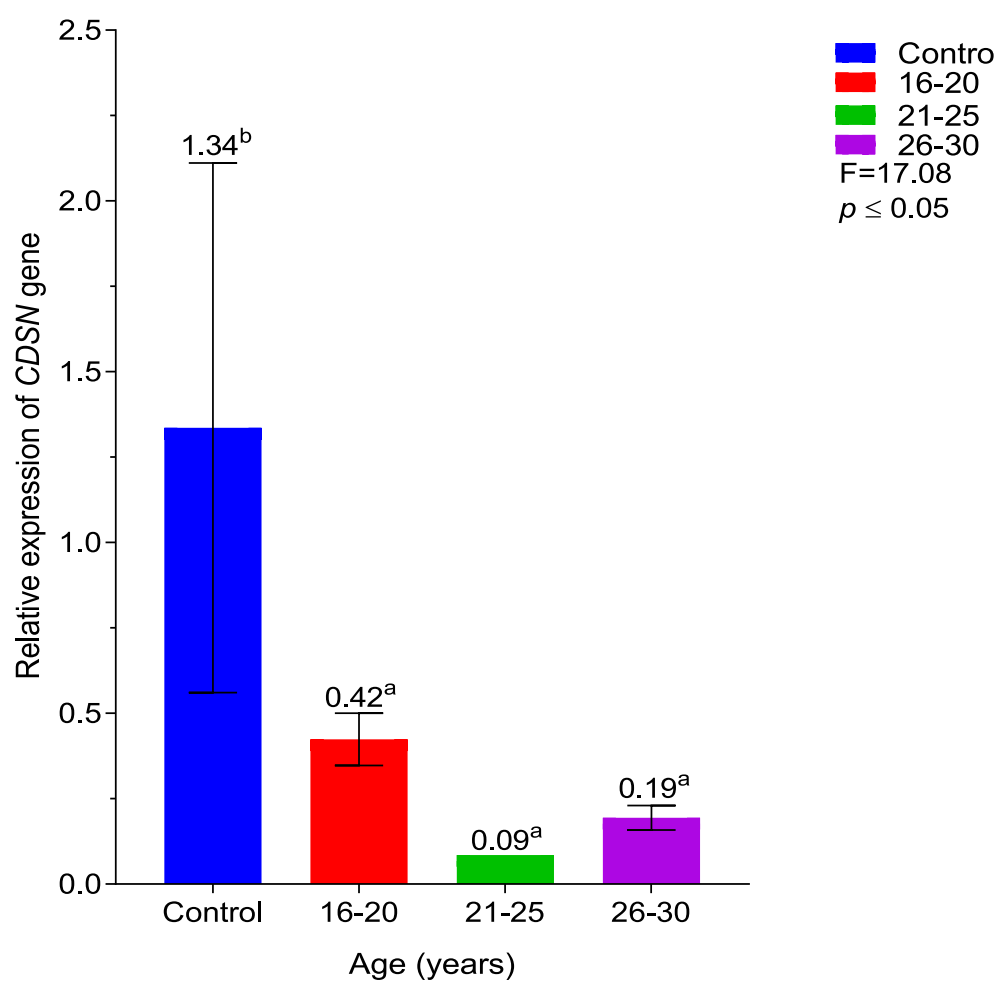

$p \leq 0.05$ 
Table 3 CDSN quantification cycle (Cq) results

\begin{tabular}{lll}
\hline & Biological set name & Cq \\
\hline 19 & A1 & 31.72 \\
18 & A2 & 35.67 \\
20 & A3 & 32.48 \\
18 & A4 & 33.78 \\
19 & A5 & 0.00 \\
24 & B1 & 33.21 \\
22 & B2 & 0.00 \\
26 & C1 & 34.32 \\
27 & C2 & 34.74 \\
26 & C3 & 34.16 \\
29 & C4 & 36.27 \\
26 & C5 & 34.26 \\
29 & C6 & 34.06 \\
27 & C7 & 34.51 \\
27 & C8 & 34.71 \\
27 & C9 & 34.52 \\
- & Control 1 & 34.85 \\
- & Control 2 & 33.37 \\
\hline
\end{tabular}

of an individual is an advantageous biometric that may be open to molecular genetic analysis. Messenger RNA (mRNA) may provide the necessary specificity, sensitivity and automation capabilities that modern forensic biology laboratories require for cellular origin identification [5]. The current study aimed at determining the age of individuals based on differences in gene expression.

The study focused on three skin-specific mRNA markers, namely, Corneodesmosin $(C D S N)$, Loricrin (LOR) and Keratin 9 (KRT9). The three target genes are involved in the differentiation or maintenance of the keratinization and cornification of the skin. KRT9 belongs to the superfamily of intermediate filament proteins that are expressed in all different epithelial cell types. About 20 human epithelial keratins exist, and each function as an important building block of the cytoskeleton of epithelial cells; also, each epithelial keratin has its own specific function or timing in the cellular dynamics. They are expressed, mostly in pairs or subsets, during terminal skin cell differentiation, in the different stages of development and in different epithelia [12]. A type I keratin, KRT9, is expressed only in the suprabasal cells of the epidermis and has previously been found to be specifically expressed in palmar and plantar skin [12]

CDSN, a 52 - to $56-\mathrm{kDa}$ basic glycoprotein, is specific to the cornified epithelia and the inner root sheath of hair follicles [13]. LOR is initially expressed in the granular layer of the epidermis during cornification and comprises about $80 \%$ of the total protein mass of the cornified envelope [14]. Both CDSN and $L O R$ are involved in the assembly of the epidermal cornified cell envelope, with CDSN mainly detected in

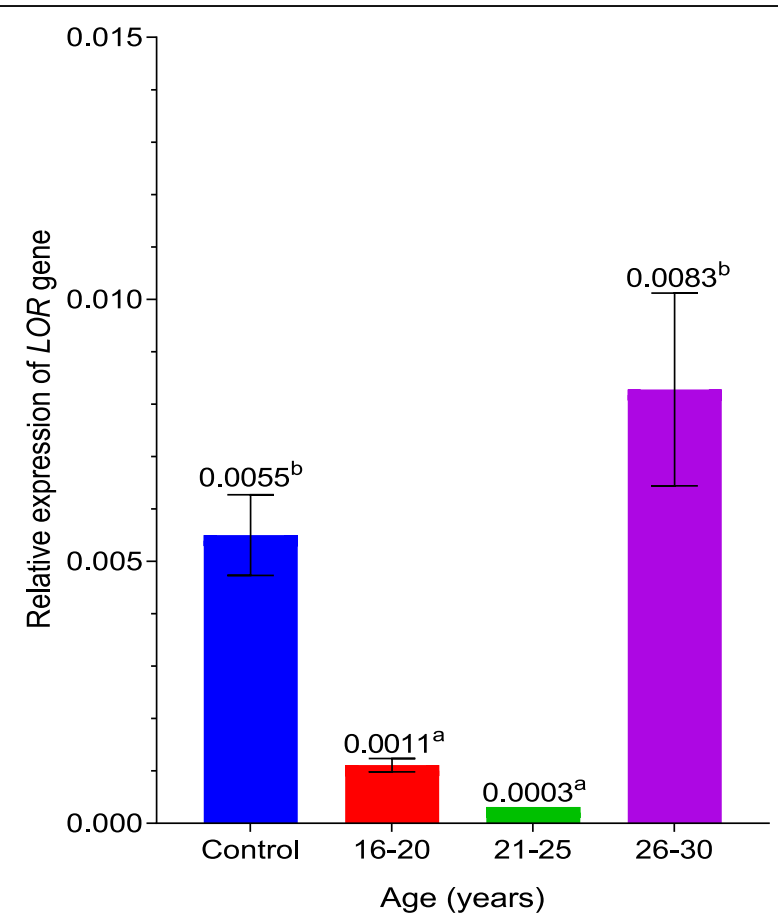

Fig. 2 Expression of the $L O R$ gene among age groups evaluated 
Table $4 L O R$ quantification Cq results

\begin{tabular}{lll}
\hline Age & Biological set name & Cq \\
\hline 19 & A1 & 34.16 \\
18 & A2 & 28.62 \\
20 & A3 & 26.44 \\
18 & A4 & 34.06 \\
19 & A5 & 35.51 \\
24 & B1 & 0.00 \\
22 & B2 & 36.10 \\
26 & C1 & 32.86 \\
27 & C2 & 26.72 \\
26 & C3 & 31.57 \\
29 & C4 & 0.00 \\
26 & C5 & 0.00 \\
29 & C6 & 36.19 \\
27 & C7 & 27.05 \\
27 & C8 & 0.00 \\
27 & C9 & 37.79 \\
- & Control 1 & 0.00 \\
- & Control 2 & 40.21 \\
\hline
\end{tabular}

uppermost spinous and granular layers [15]. Betaactin (ACTB), the reference gene used in the study was used for normalizing expression signals of skintargeted mRNA markers. It was chosen from five commonly used genes ( $\beta$-actin (ACTB), $\beta$-2microglobulin (B2M), glyceraldehyde-3-phosphate dehydrogenase (GAPDH), cyclophilin B (PPIB) and Ubiquitin C (UBC)) [16], which were all tested for ubiquitous expression across forensically relevant samples. Of all reference candidate genes, $A C T B$ has been reported to have the least variation in salivary epithelial cell [5]. Actins are highly conserved proteins that are involved in cell motility, structure and integrity. ACTB is a major component of the contractile apparatus and is also one of the two non-muscle cytoskeletal actins.

The RNA concentration and yield were very low across all samples. It was suggested that this was due to ribonucleases present in saliva, which could hinder analysis of RNA in the saliva [17]. Recent studies suggested that the method which uses a saliva-specific RNA extraction kit always produces better RNA concentration and yield characteristics as it contained a protecting solution which stabilizes salivary RNA [18]. It therefore was suggested that the low RNA concentration of the saliva samples might be due to the use

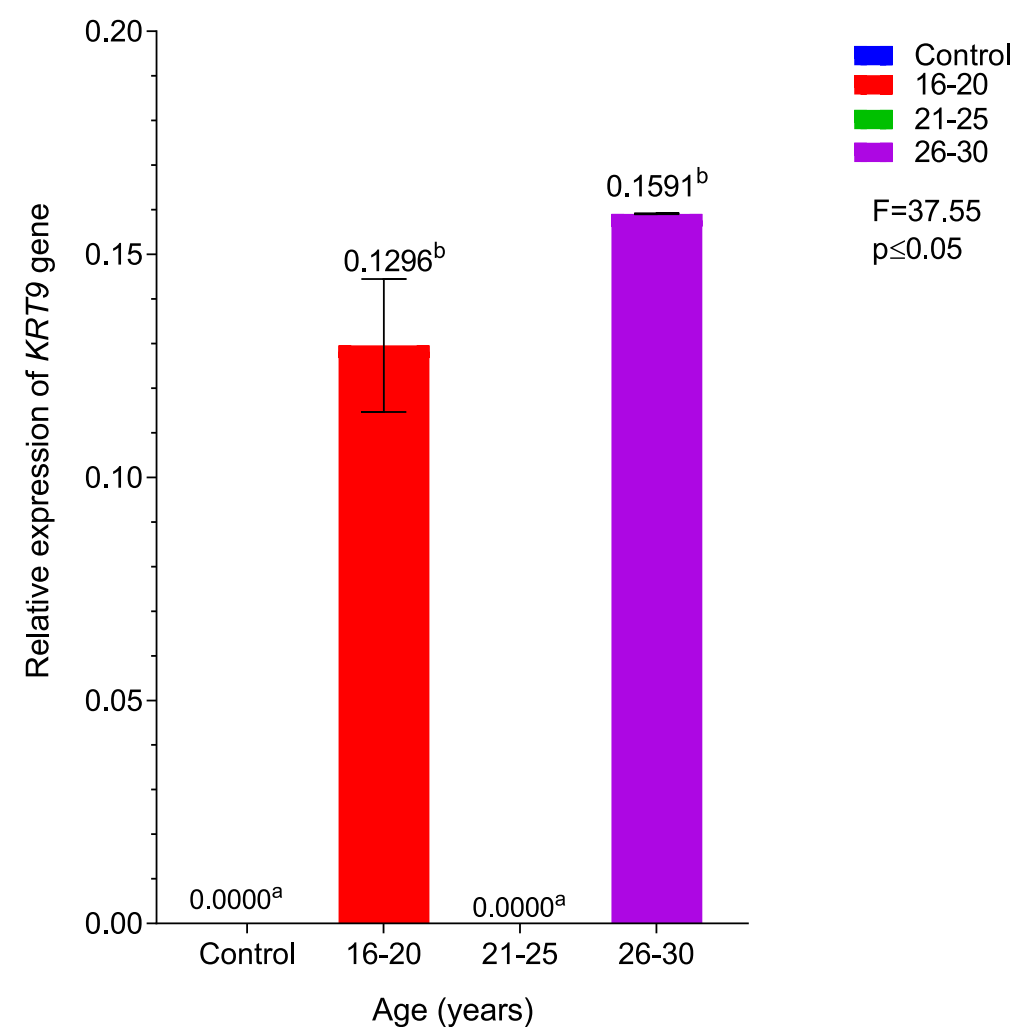

Fig. 3 Expression of the KRT9 gene among age groups evaluated 
Table 5 KRT9 quantification Cq results

\begin{tabular}{lll}
\hline Age & Biological set name & Cq \\
\hline 19 & A1 & 35.23 \\
18 & A2 & 24.28 \\
20 & A3 & 28.39 \\
18 & A4 & 0.00 \\
19 & A5 & 0.00 \\
24 & B1 & 0.00 \\
22 & B2 & 0.00 \\
26 & C1 & 35.18 \\
27 & C2 & 38.14 \\
26 & C3 & 36.06 \\
29 & C4 & 2.26 \\
26 & C5 & 23.60 \\
29 & C6 & 0.00 \\
27 & C7 & 28.84 \\
27 & C8 & 29.14 \\
27 & C9 & 16.32 \\
& Control 1 & 0.00 \\
& Control 2 & 0.00 \\
\hline
\end{tabular}

of a general RNA extraction kit and not a salivaspecific RNA extraction kit. It was observed that there was a significant $(p<0.01)$ correlation between RNA quality and RNA yield, and this can be interpreted as the less contaminated the sample is, the greater the yield expected.

The CDSN gene was detected in all the sampled age groups. Though the age group 16-20 had the highest expression of $C D S N$ among the three age groups, there was no significant difference $(p>0.05)$ in the expression of the gene among the three age groups. The expression of the CDSN gene in the control was significantly different $(F=17.08, p \leq 0.05)$ from its expression in all three age groups. The $L O R$ gene was lowly expressed across all age groups used in the study. The expression of the gene did not significantly differ $(p>0.05)$ between the control and age group 26-30, but they were however significantly higher $(F=36.47, p \leq 0.05)$ than the expression of the gene in both $16-20$ and $21-25$ age groups.
The KRT9 gene was expressed only in age groups 16-20 and 26-30 and the expression of the gene did not significantly differ $(p>0.05)$ between these age groups. The gene was not detected in the control and 21-25 age groups.

While both CDSN and $L O R$ genes were detected in all age groups which agrees with a study carried out by Visser et al. [5], KRT9 was only detected in 1620 and 26-30 age groups. Among the three genes, $C D S N$ had the highest expression across the three genes. CDSN and LOR have high sensitivity for human skin epithelial cells [19], and this can be confirmed by the presence of CDSN and LOR, though low, in all saliva samples across the three age groups, due to the fact that buccal cells which are present in the saliva have strong similarity with epithelial cells. Gomes et al. [19] reported that preliminary results suggest a probable lower sensitivity of detection for KRT9 in the analysed skin tissues, and this could account for the absence of KRT9 in the second age group (21-25).

This study was designed to define the phenotypic differences between young adults within different age groups in relation to mRNA expression levels of certain genes. Individual variation in gene expression may likely be a result of the collection of all relevant genetic influences [20]. Although RNA concentration was low and the expression values of the genes were low and could not be used in comparing the expression levels among the three age groups, it can be concluded that the three mRNA markers CDSN, $L O R$ and KRT9, as well as the ACTB reference mRNA marker analysed via the described qPCR assays, are suitable for identifying epithelial cells in saliva.

\section{Conclusion}

Messenger RNA (mRNA) analysis poses a reliable method for the positive identification of most biological materials obtained from crime scenes in forensic investigations. Studying the gene expression levels of certain skin markers of the oral epithelial cells which are present in the saliva can be incorporated into age determination on the basis of individual

Table 6 Expression values of each gene among the sampled age groups

\begin{tabular}{llll}
\hline Group & Mean \pm standard deviation (CDSN) & Mean \pm standard deviation (LOR) & Mean \pm standard deviation (KRT9) \\
\hline Control (2) & $1.336 \pm 0.7751$ & $0.0055 \pm 0.0008$ & $0.0000 \pm 0.0000$ \\
$16-20(5)$ & $0.4237 \pm 0.0766$ & $0.0011 \pm 0.0001$ & $0.1296 \pm 0.0149$ \\
$21-25(2)$ & $0.0854 \pm 0.0000$ & $0.0003 \pm 0.0000$ & $0.0000 \pm 0.0000$ \\
$26-30(9)$ & $0.1939 \pm 0.0358$ & $0.0083 \pm 0.0018$ & $0.1591 \pm 0.0001$ \\
\hline
\end{tabular}

Values are expressed in mean \pm standard deviation 


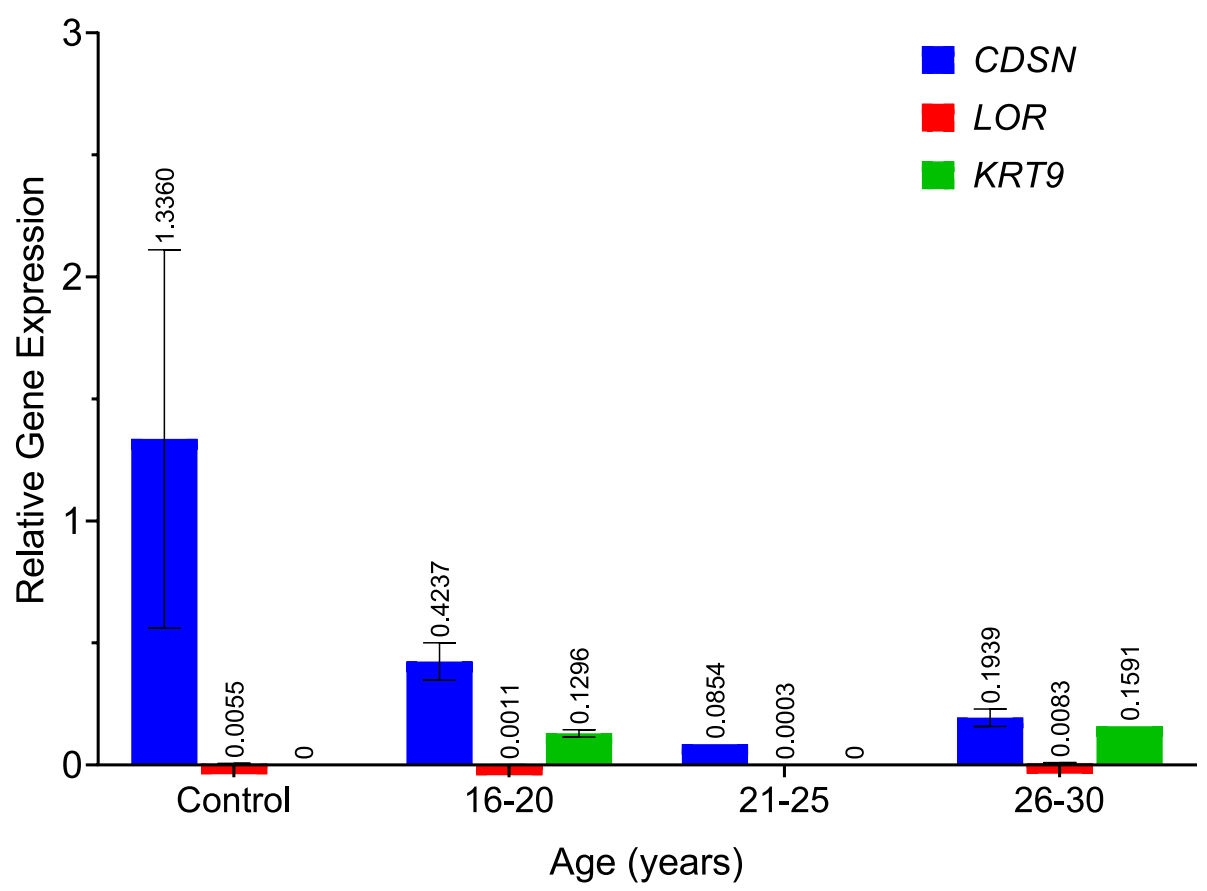

Fig. 4 Expression of the target genes (CDSN, LOR and KRT9) across all the age groups evaluated

variation in gene expression which could be a result of genetic influences. In this present study, though the expression of all the target genes was low, it was observed that gene $L O R$ expression varied among the age groups 21-25 and 26-30; therefore, more data and further analyses are still required since this experimental approach for age determination using gene expression is still at an emerging stage.

\section{Abbreviation \\ $2^{-\triangle \Lambda C t}$ method: Comparative threshold cycle (CT) method; ACTB: Beta-actin; B2M: $\beta$-2-Microglobulin; CDNA: Complementary deoxyribonucleic acid; CDSN: Corneodesmosin; Cq: Quantification cycle; GAPDH: Glyceraldehyde-3- phosphate dehydrogenase; gDNA: Genomic deoxyribonucleic acid; KRT9: Keratin 9; LOR: Loricrin; mRNA: Messenger ribonucleic acid; p: Probability value; PPIB: Cyclophilin B; qPCR: Quantitative polymerase chain reaction; RNA: Ribonucleic acid; UBC: Ubiquitin C}

\section{Acknowledgements}

We are grateful to Prof. Joy Elizabeth Okpuzor for her supervision during the course of the research

\section{Authors' contributions}

All the authors participated in the conceptualization and design of the research, carried out ribonucleic acid (RNA) extraction, complementary DNA (CDNA) synthesis and quantitative PCR (qPCR) and writing the manuscript. $\mathrm{OOI}$ and JCO coordinated the research. $\mathrm{OOI}$ supervised the research and carried out the final editing of the manuscript. All authors read and approved the final manuscript.

\section{Funding}

None.

Availability of data and materials

All data generated are reported in the manuscript.
Ethics approval and consent to participate

Prior to sample collection, what the research entails was explained to all the participants and they willingly consented to participate in the study.

Questionnaires were completed by all the study participants and informed written consent was obtained. The research protocol was approved by the Health Research ethics committee of the College of Medicine, University of Lagos (CMULHREC number, CMUL/HREC/10/19/618).

\section{Consent for publication}

'Not applicable'

\section{Competing interests}

No conflict of interest was declared by the authors.

Received: 18 March 2020 Accepted: 5 July 2020

Published online: 08 October 2020

\section{References}

1. Miletich I (2010) Introduction to salivary glands: structure, function and embryonic development. Front Oral Biol 14:1-20 https://doi.org/10.1159/ 000313703

2. Desai GS, Mathews ST (2014) Saliva as a non-invasive diagnostic tool for inflammation and insulin-resistance. World J Diabetes 5(6): 730-738. https:// doi.org/https://doi.org/10.4239/wjd.v5.16.730

3. Chiappin S, Antonelli G, Gatti R, De Palo EF (2007) Saliva specimen: a new laboratory tool for diagnostic and basic investigation. Clin Chim Acta 383(12):30-40 https://doi.org/10.1016/j.cca.2007.04.011

4. Groeger S, Meyle J (2019) Oral mucosal epithelial cells. Front Immunol 10: 208-220 https://doi.org/10.3389/fimmu.2019.00208

5. Visser M, Zubakov D, Ballantyne KN. (2011) mRNA-based skin identification for forensic applications. Int J Legal Med 125: 253-263. https://doi.org/ https://doi.org/10.1007/s00414-010-0545-2

6. Alvarez M, Ballantyne J (2006) The identification of newborns using messenger RNA profiling analysis. Anal Biochem 357(1):21-34 https://doi. org/10.1016/j.ab.2006.06.024

7. Wang Z, Zhang J, Luo H, Ye Y (2013) Screening and confirmation of microRNA markers for forensic body fluid identification. Forensic Sci Int Genet Suppl Ser 7(1):116-123 https://doi.org/10.1016/j.fsigen.2012.07.006 
8. Smith AK, Kilaru V, Klengel T, Mercer KB, Bradley B, Conneely KN, Ressler KJ Binder EB (2015) DNA extracted from saliva for methylation studies of psychiatric traits: evidence tissue specificity and relatedness to brain. Am J Med Genet B Neuropsychiatr Genet. Jan; 0(1): 36-44. https://doi.org/10. 1002/ajmg.b.32278

9. Theda C, Hwang SH, Czajko A, Loke YJ, Leong P, Craig JM (2018) Quantitation of the cellular content of saliva and buccal swab samples. Sci Rep 8:6944 https://doi.org/10.1038/s41598-018-25311-0

10. Liu J, Bian Z, Kuijpers-Jagtman AM, Von den Hoff JW (2010) Skin and oral mucosa equivalents: construction and performance. Orthod Craniofacial Res 13(1):11-20 https://doi.org/10.1111/j.1601-6343.2009.01475.x

11. Ren X, Pan L, Wang L (2014) Metabolic enzyme activities, metabolismrelated genes expression and bioaccumulation in juvenile white shrimp Litopenaeus vannamei exposed to benzo [a] pyrene. Ecotoxicol Environ Saf 104:79-86 https://doi.org/10.1016/i.ecoenv.2014.02.016

12. Su Al, Cooke MP, Ching KA, Hakak Y, Walker JR, Wiltshire T, Orth AP, Vega RG, Sapinoso LM, Mogrich A, Patapoutian A, Hampton GM, Schultz PG Hogenesch JB (2002) Large-scale analysis of the human and mouse transcriptomes. Proc Natl Acad Sci U S A99(7):4465-4470. https://doi.org/ https://doi.org/10.1073/pnas.012025199

13. Schulz MM, Buschner MGD, Leidig R, Wehner HD, Fritz P, Häbig K, Bonin M, Schütz M, Shiozawa T, Wehner F (2010) A new approach to the investigation of sexual offenses-cytoskeleton analysis reveals the origin of cells found on forensic swabs. J Forensic Sci 55:492-498 https://doi.org/10. 1111/j.1556-4029.2009.01071.x

14. Nithya S, Radhika T, Jeddy N. (2015) Loricrin - an overview. J Oral Maxillofac Pathol; 19 (1): 64-68. https://doi.org/https://doi.org/10.4103/0973-029X. 157204

15. McGrath JA (2005) Inherited disorders of desmosomes. Australas J Dermatol 46:221-229 https://doi.org/10.1111/j.1440-0960.2005.00188.x

16. Haas C, Klesser B, Maake C, Bär W, Kratzer A (2009) mRNA profiling for body fluid identification by reverse transcription endpoint PCR and realtime PCR. Forensic Sci Int Genet 3:80-88 https://doi.org/10.1016/j.fsigen.2008.11.003

17. Park NJ, Li Y, YU T, Brinkman BM, Wong DT (2006) Characterization of RNA in saliva. Clin Chem 52(6):988-994 https://doi.org/10.1373/clinchem.2005. 063206

18. Madera MV Causado AS (2017) Evaluation of two RNA extraction methods in children's saliva. Rev Odont Mex 21(4):237-243 https://doi.org/10.1016/j. rodmex.2018.01.014

19. Gomes I, Kohlmeier F, Schneider PM (2011) Genetic markers for body fluid and tissue identification in forensics. Forensic Sci Int Genet Suppl Ser 3:469470 https://doi.org/10.1016/j.fsigss.2011.09.096

20. Cowley MJ, Cotsapas CJ, Williams RB, Chan EK, Pulvers JN, Liu MY, Luo OJ, Nott DJ, Little PFR (2009) Intra- and inter-individual genetic differences in gene expression. Mamm Genome; 20(5):281-295. https://doi.org/https://doi. org/10.1007/s00335-009-9181-X

\section{Publisher's Note}

Springer Nature remains neutral with regard to jurisdictional claims in published maps and institutional affiliations.

\section{Submit your manuscript to a SpringerOpen ${ }^{\circ}$ journal and benefit from:}

- Convenient online submission

- Rigorous peer review

- Open access: articles freely available online

- High visibility within the field

- Retaining the copyright to your article

Submit your next manuscript at $\boldsymbol{\nabla}$ springeropen.com 